\title{
Jakes Gerwel (1946-2012): Humble intellectual, scholar and leader
}

AUTHOR:

Saleem Badat $^{1}$

\section{AFFILIATION:}

'Vice-Chancellor's Office, Rhodes University,

Grahamstown, South Africa

\section{CORRESPONDENCE TO: \\ Saleem Badat}

EMAIL:

vc@ru.ac.za

\section{POSTAL ADDRESS:}

Vice-Chancellor's Office,

Rhodes University, P0 Box 94, Grahamstown 6140, South

Africa

\section{HOW TO CITE:}

Badat S. Jakes Gerwel (19462012): Humble intellectual, scholar and leader. S Afr J Sci. 2013;109(1/2), Art. \#a006, 2 pages. http://dx.doi.org/10.1590/ sajs.2013/a006

(c) 2013. The Authors.

Published under a Creative Commons Attribution Licence.
Media commentaries and tributes on the passing of Jakes Gerwel were unanimous: South Africa has lost an exceptional humble intellectual, scholar and leader, and "a good and great man" who provided wise counsel to people in leadership positions in the higher education, political, business, sporting and philanthropic worlds. His death leaves a "big void" in South Africa. Antjie Krog wrote: "South Africa has lost its most broad-minded thinker and its most loyal critic who matters".

Gert Johannes Gerwel was born in 1946 on a sheep farm in Kommadagga, midway between Grahamstown and Somerset East in the Eastern Cape. Primary education at a church farm school was followed by secondary schooling at Dower College in Uitenhage and Paterson High School in Port Elizabeth. Thereafter, in 1965, Gerwel proceeded to the University of the Western Cape (UWC) and graduated cum laude in Afrikaans-Nederlands and obtained an honours degree in the same discipline.

After lecturing Afrikaans at Hewat Training College in Athlone, he attended the Vrije Universiteit of Brussels and completed a licentiate in Germanic Philology on a Belgian government scholarship. He graduated from the Vrije Universiteit with a doctorate in Literature and Philosophy for a thesis entitled 'Literatuur and Apartheid'. Joining UWC as an academic, he became a professor in 1980 and Dean of the Arts Faculty in 1982. In 1987 he was appointed Vice-Chancellor.

Gerwel was an exceptional, courageous and pioneering South African intellectual, scholar, leader, activist and citizen with a deep commitment to equity, social justice and democracy. A product of historically disadvantaged schools in the Eastern Cape, he had to triumph over the Verwoerdian dictum that there was no place for Blacks beyond being hewers of wood and drawers of water. In a country deeply challenged to improve schooling and realise the potential of all youth, his example of a rural boy who achieved remarkable success under adverse conditions must serve as a source of inspiration for young people who struggle under the burden of dismal educational opportunities.

Through a long and distinguished association with the higher education sector, as an academic, dean, vice chancellor, Chairperson of the Committee of University Principals in the early 1990s, Chancellor of Rhodes University, and Chairperson of the Mandela Rhodes Foundation, Gerwel was an outstanding champion of higher education.

On 05 June 1987, at the age of 41, he became the first radical Vice-Chancellor of UWC - indeed, of any South African university. He boldly rejected the apartheid principles on which UWC had been established. Noting that the "Afrikaans universities stand firmly within the operative context of Afrikaner nationalism", and that the Englishlanguage universities operate within the contexts of "anglophile liberalism", he observed that there was no university linked to "those people and institutions working for a fundamental transformation of the old settler-colonial order".

He declared that UWC faced "the historical imperative to respond to the democratic left, to be an intellectual home for the left"; it had to "develop a critical alignment with the democratic movement" and had to "educate towards and for a changed society". Gerwel stated that he could not "in conscience, in truth, educate or lead education, towards the reproduction and maintenance of a social order which is undemocratic, discriminatory, exploitative and repressive". Universities, instead, had to promote "through example a democratic culture". Gerwel was too good and thoughtful an intellectual to reduce a university to a political institution. He observed that a university can never "have a corporate opinion" nor compromise its "essential identity as 'disinterested' searchers after truth".

President Mandela noted that "the nation drew inspiration from [UWC's] defiant transformation of itself from an apartheid ethnic institution into a proud national asset: from its concrete and manifest concern for the poor, for women and rural communities, and from its readiness to grapple with the kinds of problems that a free and democratic South Africa was to deal with later". Archbishop Desmond Tutu recalled Gerwel saying, especially at a time when it was unpopular, "We are on the side of the downtrodden, we are going to work for the upliftment of our people".

UWC committed itself to non-racialism, non-sexism and social justice and "the development of the Third World communities in South Africa". Access was opened to all South Africans and UWC began to ditch its previous baggage as a 'Coloured' and 'bush' university. Intellectual debate flourished and UWC became an exciting space for socially committed and engaged scholarship. There was educational innovation that was years ahead of any other university. One area of profound work was in academic development programmes, which sought to provide 'epistemological access' and equity of opportunity for the poor. Many Black intellectuals and scholars owe their achievements and positions to Gerwel's bold and inspired leadership and the exciting intellectual environment that he cultivated at UWC.

Gerwel helped to advance gender equity significantly at UWC. Compared to men, women at UWC suffered many disabilities related to salaries, benefits, pensions, leave and the like. While the efforts of women at UWC were decisive, as Desiree Lewis wrote:

Gerwel played a central role in fostering the spaces, frameworks and contexts for integrating discourses on gender into progressive thinking about democratic transformation in the early 1990s. I would like to think of individuals such as...Jakes Gerwel as models of leadership for young women today. 
[His] leadership demonstrated an organic and spontaneous receptiveness to the new, a visionary confidence in the knowledge of socially subordinate subjects.

The early 1990s saw UWC become a key site for policy research in support of a just and democratic South Africa. Gerwel brought scholars working in isolation on higher education, constitutional, economic, trade, health and other policy issues together in a common conversation on meta-issues such as the meaning of policy, the context of policy formation and implementation. Many of those involved in this policy work became cabinet ministers and leaders of institutions post- 1994 .

On accepting an honorary doctorate from Rhodes, Gerwel stated:

Universities are both central agents for change and steady beacons of continuity and tradition. As we feel buffeted by the storms of change, their presence and functioning in society should provide a sense of succor and solace that our changes are underpinned by centuries-old traditions of reasoning and enquiry. When we get despondent about things not changing, they should provide assurance and encouragement that there are fresh and courageous minds of our intellectual elite grappling with and giving lead in changing our lives and our patterns of thought.

This statement is wise counsel for South African universities. So too is his advocacy of the need to pursue in principled and creative ways equity with excellence and excellence with equity.

Gerwel was an important beacon in the economic, social and political life of South Africa. The numerous honorary doctorates awarded to him and his extensive leadership roles in civil society, business and sport organisations are testimony to the great respect that he enjoyed in all quarters of society.

Recognising Gerwel's intellect, integrity, circumspect nature and pragmatic approach, Nelson Mandela invited him to become democratic South Africa's first Director General in the Office of the President and Cabinet Secretary. According to Joel Netshitenze:

His approach to the establishment of the Office of the President is a study in the calm management of a transition. The honest and deliberate way in which he sought to ease the remaining staff of the 'old order' into the new dispensation was as critical to a smooth transition as the celebrated efforts of President Nelson Mandela and other political leaders. He handled the apprehensions of the 'old staff' and the impatience of the new with a deftness that came to characterise the stability of our transition within the state and in broader society.
Netshitenze added that, ever the scholar, "Gerwel sought to generalise his experiences, as if he was on a mission to develop study material for a course in state politics and public administration".

Departing office with Mandela in 1999, he was to become a close confidant of Mandela, chair of the Nelson Mandela Foundation and his emissary on important political missions. The CEO of the Mandela Rhodes Foundation, Shaun Johnson, wrote:

\section{Without Jakes Gerwel's contribution there would be no Nelson Mandela Centre of Memory, no Mandela Rhodes Foundation, and no Mandela Rhodes Scholars. Talk about leaving a legacy - these things would be lifetime achievements for most people, but in the case of Jakes they are a couple of sparkling pieces in a much larger kaleidoscope.}

Today, too many politicians, businesspersons and state officials have as their god accumulation through bribery, corruption and looting of the state. Jakes Gerwel, in contrast, is a magnificent symbol of intellectual, academic, social and personal integrity, and ethical professional conduct in the service of human good. He leaves a powerful legacy of bold leadership, critical scholarship, commitment to social justice and a humane society, and social action towards these ends. Koos Bekker, CEO of Naspers, said that he had examined some dictionaries for the antonym of 'racist' but could not find one. He concluded that the word should be 'Jakes'.

Knowledge and intellectual labour seem to be disdained in contemporary South Africa. Gerwel valued knowledge and took intellectual work very seriously. He was wont to point out to the more action-oriented: "Good intellectual work entails hard work of a special type. It is as difficult, if not more difficult, than organising door-to-door work, street committees and mass rallies".

What Colin Bundy has noted with respect to the late scholar Harold Wolpe applies equally to Gerwel: "He was one of those rare academics who give intellectuals a good name". What Gerwel has written about Wolpe can also be said of him:

\section{He was one of those citizens and intellectuals who, to borrow an evocative phrase from Habermas, never neglected to make public use of his reason at every point: whether as teacher and mentor, as scholar, as member of the liberation movement, as public intellectual, as interlocutor in private conversation.}

A former Rhodes SRC president wrote: "He ran his race, it is now complete. Others must take over from where he left off". Indeed!

Hambe kahle, bold, humble and gentle man, leader and mentor of great integrity and intellect and dry and understated wit. You will be dearly missed. 